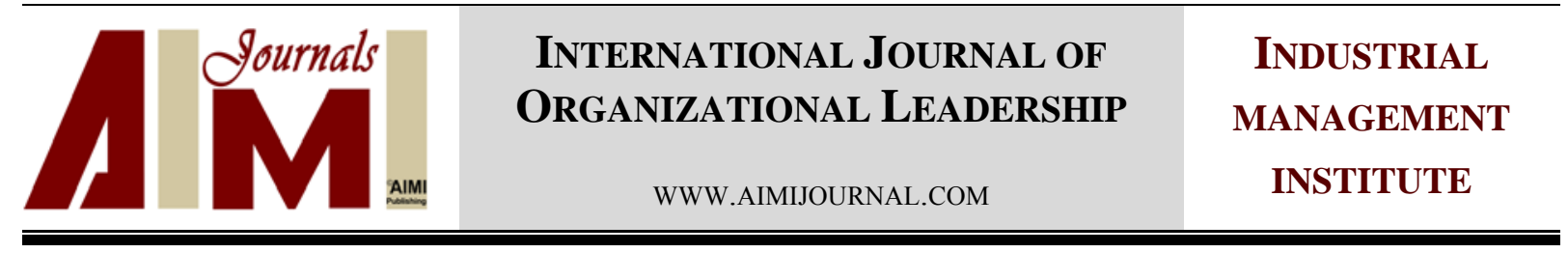

\title{
The effect of strategic leadership and empowerment on job satisfaction of the employees of University of Guilan
}

\author{
Mostafa Ebrahimpour Azbari ${ }^{1}$, Mohsen Akbari ${ }^{2}$, Milad Hooshmand Chaijani ${ }^{3 *}$ \\ ${ }^{1,2}$ Department of Humanities, University of Guilan, Rasht, Iran \\ ${ }^{3} \mathrm{PhD}$ Candidate of Business Management, University of Tehran, Tehran, Iran
}

\begin{abstract}
Keywords:

Strategic Leadership, Job Satisfaction, Employee Empowerment, Structural Equation Modeling

Correspondence: hooshmand.milad@ut.ac.ir

The methods for the management and leadership of educational and research organizations has always been a question of some researchers. With the emergence of the strategic management in educational organizations, different views were raised about the management of these institutions whether it is possible to apply issues related to the business and educational administration field. They both agree on the difference between educational environment and business environment. This difference leads to different research areas which one of them is the managers' educational leadership style. Regarding to the educational research centers' management, strategic leadership is one of leadership styles. This paper examined the effect of this leadership style on empowerment and job satisfaction of employees of Guilan University. The statistical population of the study consisted of 235 employees of Guilan University. Smart PLS software and Structural Equation Modeling were used for data analysis. The results showed that the style of strategic leadership and employee empowerment had a significant positive effect on job satisfaction.
\end{abstract}

It is clear that organizations confront with more than one market (employees as the internal market and customers as external market). This view reveals that employees' job satisfaction is an image of the external customers' satisfaction (Bellou \& Andronikidis, 2008; Masihabadi, Rajaei, Koloukhi, \& Parsian, 2015). Thus, employees are considered as the most important source of competitive advantage for an organization or an economic entity. In fact, they can succeed or fail an organization. The important concerns of successful businesses are 
gathering educated and intellectual human capital in order to be able to change the organization.

A successful organization is considered as a group of people with organizational culture, ideas, and common goals that work together in a flexible system of organization employing their own experiences and knowledge for the organizational development. On the other hand, job satisfaction is one of the most important and perhaps the most controversial concepts that are of prime importance at all levels of management and human resources of organizations (Avery, Smillie, \& Fife-Schaw, 2015; Bessokirnaia \& Temnitskii, 2015; Beteta, 2006; Burke, Oberklaid, \& Burgess, 2005; Cahill, McNamara, Pitt-Catsouphes, \& Valcour, 2015; Chan \& Qiu, 2011; B. J. Davies \& B. Davies, 2006; Gius, 2013; Grube, Schroer, Hentzschel, \& Hertel, 2008; Jones \& Sloane, 2007; Kurland \& Hasson-Gilad, 2015; Metle, 2001; Wolfe \& Kim, 2013). Today, job satisfaction is an indicator of the managerial and leadership's effectiveness. Managers can adopt an appropriate leadership style to increase employees' motivation and thereby increase their efficiency, productivity, organizational commitment, and customers' satisfaction (Akhtar Shojaei, Nazari, \& Vahidi, 2004). All these provide appropriate circumstances for organizations to empower employees and satisfy customers and as a result, promote their organizational performance.

All management objectives mentioned can empower employees and turns them into actions. Leadership is considered as one of the important and especial methods for the empowerment and employees' satisfaction (Ghahremani Germi \& Hasanzadeh, 2015). Leadership can be defined as the ability to influence others to achieve the intended goals. Leader is the person who is able to convince others to work in order to achieve organizational goals (Yukl, 1994). In fact, many researchers consider the role of leadership to be of prime importance for successful and unsuccessful organizations and say that without leadership, organizations are only a detached and dispersed set of people and offices. How to manage and lead the organizations has always been fundamental question for some of the researchers. By introducing the strategic management to the organizations, different views were raised about the management according to today's conditions (Al Hijji, 2014; Antoniou \& Ansoff, 2004; Barnes, Hinton, \& Mieczkowska, 2004; Gannon, Roper, \& Doherty, 2015; Jackson, Schuler, \& Jiang, 2014; Keupp, Palmié, \& Gassmann, 2012; Maranville, ,2011; Okumus, Wong, \& Altinay, 2009; Poister, 2005; Reich, 2015; Weinberg \& Lewis, 2009; Yorio, Willmer, \& Moore, 2015). In order to meet the requirements of highly competitive environment and ever-changing economic issues, many of these leadership styles were adopted and their results showed the optimum use of organizational resources and gaining the maximum advantage compared to other competitors. The strategic leadership style is among the leadership styles discussed in the management of today's organizations and its role in creating a competitive advantage is controversial. This study relying on strategic leadership examined its effects on the empowerment and job satisfaction of employees of Guilan University. In fact, the distinction made in the present study is introducing the strategic leadership in Iranian organizations; especially educational organizations. Therefore, the analysis of present model's relationships used in the current study was done by examining the theoretical base and achieving to a precise framework. 


\section{Theoretical Framework}

The most important factor on organizational efficiency and, ultimately the whole of the society is its human resources. Human resource development system in any organization should develop new ways to improve workforce management in order to have a positive impact on employees' performance and productivity. Many researchers acknowledge that one of the ways is to increase motivation and employees empowerment (Chen, Liaw, \& Lee, 2003; Liu, Chiu, \& Fellows, 2007). Studies done in the leadership and management skills consider empowerment as the essential component of management effectiveness and also as a tool to increase motivation and improve efficiency in the organizations (Ozaralli, 2003). The empowerment, in turn, is a motivational process in which individual experience was considered as a sense of empowerment (Yagil, 2006). In fact, empowerment is associated with the employees' understanding of the control power and the sense of independence in their work. This causes the person who has high energy, strengthens the sense of selfdetermination, self-worth, and self-efficacy too (Conger \& Kanungo, 1988). Studies also showed that customer satisfaction is an important result of empowerment (Seibert, Silver, \& Randolph, 2004). The importance of empowerment and job satisfaction in itself can imply the importance of drawing more attention to leadership style and personnel management, since leadership plays a key role in forming the components of the organization and help the employees to do their tasks efficiently (Amundsen \& Martinsen, 2014; Bessokirnaia \& Temnitskii, 2015; Ertürk \& Vurgun, 2015; Hennestad, 1998; Hill, Kang, \& Seo, 2014; Larkin \& Milne,2014; Lin, 2002; Kanagaretnam et al., 2014; Menon, 2001; Pezeshki-Rad, Biglari, \& Zamani-Miandashti, 2011; Rowlinson \& Cheung, 2008; Tutuncu \& Kozak,2007; Ueno, 2008).

In fact, leadership is defined as a process of influencing the activities of the group in order to achieve the objectives. Managers try to influence the people under their supervision and direct and motivate them to achieve their organizational goals. Motivating employees to work willingly and do their best to achieve the organizational goals are the managers' hardest tasks. The type of behaviors that accompanies the leader's success is a function of the characteristics of the time and place circumstances (Zahedi, 1999).

Leadership in educational and research organizations is highly sensitive matter, because in such organizations, educated people are considered as human resources (as employees and faculty) as well as the customers as student or any other external institutions (Davies, 2003).

One of the basic questions that always have attracted the minds of researchers, universities, and organizations is the leadership style and what attributes to those attitudes and styles that distinguish the leaders. Many theories have been provided about leaders' differences that one of these theories are known as theories of leadership styles. Despite the fact that the strategy concept is one of the components of educational administration, the theoretical and practical domains of this field are discussed more recently (El-Hout, 1994). For the first time in the 80 's, the concept of strategy introduced into the literature of educational administration. However, until 1988, little attention was paid to it (Fidler, 1989). In 1988, Britain passed an education reform law in which all universities should have a development plan. The consequences of employing the strategic leadership in such organizations include the specific orientation of organizations, translation of strategy into 
operations, empowering employees in designing and implementing the strategy, determining key points, cooperating in the task, and developing empowerment strategy (B. J. Davies \& B. Davies, 2006).

Research on strategic leadership focuses on the managers who have ultimate responsibility of the organization (Hambrick \& Mason, 1984). Researchers employ the framework proposed by Bass $(1985,1998)$ to identify the strategic leadership. This framework consisted of transformational and transactional leadership and explained the performance of top managers (Lenkov, Judge, \& Wright, 2005; Waldman, Siegel, \& Javidan, 2006) and included variables in organizational level such as structure, culture, learning, and innovation (Pawar \& Eastman, 1997; Vera \& Crossan, 2004). Transformational leadership consists of encouragement and intellectual stimulation, attention to individual differences, the ideal influence, and the ideal motivation (Avolio, Bass, \& Jung, 1999). Intellectual stimulation is defined as the degree that leaders encourage their subordinates to be creative and innovative (Bass, Avolio, Jung, \& Berson, 2003). Attention to individual differences refers to the degree to which a leader pays attention to individual's special needs. Ideal influence is defined as the degree to which the followers feel a leader is trustworthy, honorable, and praiseworthy. Ideal motivation refers to the degree to which a leader creates an organizational prospect and moves all in that direction (Banihashemian, Golestan Jahromi, Ganbari Pirkashani, \& Sharafi, 2011). Transactional leadership consists of two types of behavior; the rewards contingency and active management by exception. Through rewards contingency, leaders determine what followers to do and also what is the appropriate reward for them. Through active management by exception, leaders inspect followers' behaviors, but in some necessary cases, exceptions can be granted.

\section{The Literature Review}

Various studies have been done on variables such as satisfaction, empowerment, leadership in the general concept and strategic leadership in the specific concept.

Ehsani, Sedaghati, and Ghanbari (2012) in their study on nurses employed in a hospital affiliated to the Tonekabon Azad University concluded that leadership style had a direct and significant impact on job satisfaction and this relationship ultimately increased organizational commitment, quality services, and as a result, increased patients' satisfaction.

Kharrazi, Mir Kamali, and Torki (2013) in a study done on employees of National Bank, tried to identify the relationship between leadership style and job satisfaction. They found that there was a positive and significant relationship between them, and leadership component was the strongest predictor of job satisfaction.

Banihashemian et al. (2011) in a study concerned with the factors affecting job satisfaction in employees of Shiraz University of Medical Sciences concluded that the relationship between the managers' public health and the chosen leadership style was significant and positive as the same as employees' leadership style and their job satisfaction.

Hassanpour, Abbasi, and Norouzi (2011) revealed that transformational leadership style plays a key role in employee empowerment and also stated that this style had a significant relationship with a sense of competence, a sense of choice, a sense of effectiveness, and meaningfulness as well as a sense of trust in others. In this regard, Esfahani, Ghazanfari and Amerinasab (2013) investigated the correlation between ethical leadership and empowerment 
and came to the conclusion that there was a significant positive correlation between these two variables.

Mir Kamali, Hayat, Norouzi, and Jarahi (2009) examined the relationship of psychological empowerment, job satisfaction and organizational commitment among employees at Tehran University and concluded that the relationship between employee empowerment and job satisfaction and commitment was positive and significant. Mir Kamali and Nasti Zaei (2010) evaluated the relationship between the employee empowerment and job satisfaction among nurses and proved a positive relationship between them.

Lenkov, Judge, and Wright (2005) studied strategic leadership among different cultures and explored its role on innovative influence of the senior managers.

Jansen, Dusya, and Crossan (2009) explored the role of strategic leadership in exploitation of organizational innovations and considered strategic leadership in two dimensions of transactional leadership and transformational leadership. Based on his findings, strategic leadership developed creative thinking and organizational innovation. Transactional leadership helps to the exploitation of innovations and existing knowledge. Thus, according to the presentation of theoretical framework derived from the previous studies, the following figure is offered as the theoretical framework of the present study.

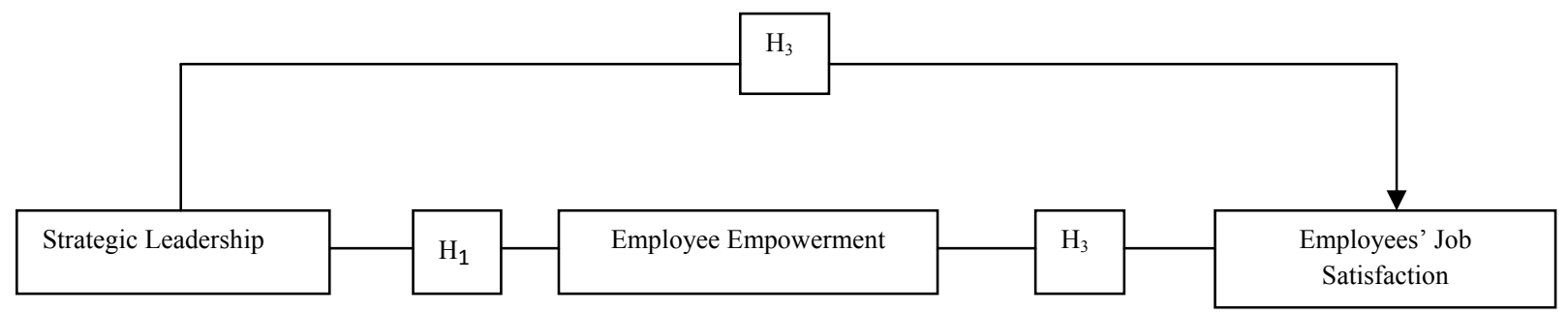

Figure 1. Tahghi's theoretical framework

\section{Research Hypotheses}

In line with the discussion above, the following research hypotheses were formulated:

$\mathbf{H}_{1}$ : Strategic leadership influences employee empowerment.

$\mathbf{H}_{2}$ : Empowerment influences employee job satisfaction.

$\mathbf{H}_{3}$ : Strategic leadership influences employee job satisfaction.

\section{Method}

This study fits within the category of descriptive research. The statistical population of the study consisted of 235 out of 600 employees of Guilan University. The data were obtained using the simple random sampling method. The instrument used in this study were questionnaires including questions related to employees' job satisfaction (fifteen questions taken from questionnaires of Jung and Yoon 2013), empowerment (fourteen questions derived from questionnaires of Hayes, 1994), as well as strategic leadership (seven questions, derived from questionnaires Lenkov et al., 2005). Participants were instructed to rate 
themselves using a five point Likert-Scale ranging from strongly disagree (1 point) to strongly agree (5 points).

\section{Results}

The partial least squares approach to structural equation modeling (SEM) in the Smart PLS 2 software were employed to examine the conceptual model. This method is one of the best tools for analysis of studies in which the relationships between variables are complex; the sample size is small and the distribution of data is abnormal (Diamantopoulos, Sarstedt, Fuchs, Wilczynski, \& Kaiser, 2012). In addition, to measure the causal relationship, partial least squares method (PLS) is the perfect method (Henseler, Ringle, \& Sinkovics, 2009). To illustrate and explain the data collected in this study, some characteristics of respondents were shown in Table 1.

Table 1

The Demographics of the Sample

\begin{tabular}{cccc}
\hline & Dimensions & Frequency & Percentage \\
\hline Sex & Male & 162 & 64.7 \\
& Female & 88 & 35.3 \\
& $5<$ & 30 & 12.1 \\
Job Experience & $5-10$ & 65 & 26.2 \\
& $10-15$ & 49 & 19.1 \\
& $15-20$ & 28 & 11.3 \\
Academic Degree & $20-25$ & 44 & 17.7 \\
& High School & 70 & 27.9 \\
& AS & 37 & 15 \\
& BS & 96 & 38.6 \\
& MS \& Ph.D & 47 & 18.6 \\
Types of Employment & Part-time Employment & 81 & 32.4 \\
& Fixed- time Employment & 41 & 16.5 \\
& Subject to Labor Law & 34 & 13.7 \\
\hline
\end{tabular}

To assess the reliability index of the measurement model, convergent validity and divergent validity were used. Reliability index for measuring inter-rater reliability includes three criteria, namely Cronbach's alpha, composite reliability, factor loadings.

\section{Measurement of Factor Loadings Measures}

Factor loadings are determined by calculating the correlation of the indicators of one structure, and its proper value is equal to or greater than 0.4 (Hulland, 1999). It indicates that the variance between the structure and its indicators is greater than of measurement error variance. Factor loadings resulting from the implementation of the model in Table 2 reveals that all indicators have proper factor loadings. It became clear that the fifth and seventh components of employees empowerment indicator and the sixth indicator of job satisfaction was not significant and its factor loadings was less than 0.4 (its statistic value was less than 1.96); therefore, they were excluded from the calculations. 
Table 2

Loading Factors of Measures of Model

\begin{tabular}{|c|c|c|c|c|c|c|c|c|}
\hline & $\begin{array}{l}\text { Measures } \\
\text { Code }\end{array}$ & $\begin{array}{l}\text { Load Factor } \\
\quad(\geq 0 / 4)\end{array}$ & Structure & $\begin{array}{l}\text { Measure } \\
\text { Code }\end{array}$ & $\begin{array}{l}\text { Load Factor } \\
\quad(\geq 0 / 4)\end{array}$ & Structure & $\begin{array}{l}\text { Measures } \\
\text { Code }\end{array}$ & $\begin{array}{l}\text { Load Factor } \\
\quad(\geq 0 / 4)\end{array}$ \\
\hline & EE1 & 0.62 & & EE14 & 0.42 & & JS12 & 0.70 \\
\hline & EE2 & 0.59 & & JS1 & 0.58 & & JS13 & 0.73 \\
\hline & EE3 & 0.44 & & JS2 & 0.59 & & JS14 & 0.79 \\
\hline & EE4 & 0.69 & & JS3 & 0.54 & & JS15 & 0.75 \\
\hline & EE6 & 0.62 & & JS4 & 0.48 & & TSL1 & 0.85 \\
\hline & EE8 & 0.54 & & JS5 & 0.67 & TSL & TSL2 & 0.91 \\
\hline & EE9 & 0.67 & & JS7 & 0.68 & & TSL3 & 0.91 \\
\hline \multirow[t]{4}{*}{$\mathrm{EE}$} & EE10 & 0.57 & JS & JS8 & 0.52 & & MSL1 & 0.88 \\
\hline & EE11 & 0.63 & & JS9 & 0.48 & SL & MSL2 & 0.91 \\
\hline & EE12 & 0.56 & & JS10 & 0.57 & MSL & MSL3 & 0.88 \\
\hline & EE13 & 0.64 & & JS11 & 0.59 & & MSL4 & 0.87 \\
\hline
\end{tabular}

Cronbach's alpha offers a classic indicator for reliability analysis and represents a strong tradition in structural equations which estimate reliability based on the internal consistency and a proper value for it is greater than 0.7 (Cronbach, 1951). In order to calculate reliability, there are some other criteria that have more advantages compared to the traditional method of calculating it by Cronbach's alpha, which is called composite reliability (CR). Superiority of composite reliability to the Cronbach's alpha is that the reliability of structures is calculated regarding their structural consistency. As a result, for better measurement of reliability, both of these criteria are used. For the composite reliability, 0.7 is considered as the proper value (Nunnally, 1978). Fornell and Larcker (1981) suggested using the average variance extracted (AVE) as a measure of convergent validity. The criterion for the desirability of AVE is greater than 0.5 .

Table 3

Report of Criteria of Cronbach's Alpha, Composite Reliability,and Convergent Validity

\begin{tabular}{lcccc}
\multicolumn{1}{c}{ Latent Variable } & Title of the Model & $\begin{array}{c}\text { Cronbach's Alpha } \\
\text { Coefficients } \\
\text { (Alpha } \geq 0.7)\end{array}$ & $\begin{array}{c}\text { Composite Reliability } \\
\text { (CR } \geq 0.7)\end{array}$ & $\begin{array}{c}\text { The Average Variance } \\
\text { Extracted }\end{array}$ \\
\hline Strategic Leadership & SL & 0.93 & 0.90 & 0.74 \\
Transformational & TSL & 0.87 & 0.92 & 0.81 \\
Transactional & MSL & 0.91 & 0.93 & 0.78 \\
Employees & EE & 0.83 & 0.89 & 0.61 \\
Empowerment & JS & 0.87 & & 0.53 \\
Job Satisfaction & & & & 0.86 \\
\hline
\end{tabular}

Regarding the values of Cronbach's alpha and composite reliability reported in Table 3, all latent variables has a Cronbach's alpha value and composite reliability higher than 0.7 indicating that the model has a proper validity. As well as, the average variance extracted (AVE) for latent variables is higher than 0.5 . The convergent validity of the measurement models is desirable too.

To investigate the divergent validity of the measurement model, Fornell and Larcker (1981) criteria was used. Based on these criteria, acceptable divergent validity of the model suggests that a structure in a model which has more interaction with their indicators than other structures. Fornell and Larcker (1981) explained that the divergent validity is at an acceptable level when AVE for each structure is more than shared variance between that structure and other structures of the model. It is investigated by Smart PLS software in which 
the houses of the matrix contain values of correlation coefficient between the structures and the square root of AVE values of each structure shown in Table 4.

Table 4

Correlation between Latent Variables and Output Values of $A V$ and also $R^{2}$ and $Q^{2}$

\begin{tabular}{cccccccc}
\hline & EE & JS & MSL & SL & TSL & $\mathrm{R}^{2}$ & $\mathrm{Q}^{2}$ \\
\hline EE & 0.78 & & & & & 0.22 & 0.17 \\
JS & 0.51 & 0.73 & & & & 0.45 & 0.21 \\
MSL & 0.41 & 0.61 & 0.88 & & & 0.92 & 0.71 \\
SL & 0.45 & 0.60 & 0.84 & 0.86 & & - & - \\
TSL & 0.44 & 0.52 & 0.78 & 0.82 & 0.89 & 0.85 & 0.67 \\
\hline
\end{tabular}

As it has been presented in Table 4, according to the results of correlation and the root of AVE, the divergent validity of the model in the structure is obtained based on the Fornell and Larcker measure. After measuring the validity and reliability of the measurement model, the structural model was evaluated through the relationship between latent variables. In this study, the three criteria including a significance of coefficient (t-values), the coefficient of determination $\left(\mathrm{R}^{2}\right)$ and coefficient of prediction power $\left(\mathrm{Q}^{2}\right)$ were used. The first measure in structural model is coefficient significance. The coefficients implemented for the model were shown in Figure 2. Accordingly, all of the significant coefficients were more than 3.27 which showed the meaningful relationships between variables at a confidence level of 99.9 per cent. The results obtained from the analysis of the structural model presented in Table 4, showed the measure of $\mathrm{R}^{2}$ (R Squares) for all the endogenous variables in the model. The results of this measure showed that according to the survey conducted by Chin (1998) the fitness of the structural model has been generally good. In addition, to evaluate the predictive power of the model, a criterion called $\mathrm{Q}^{2}$ (Stone-Geisser criterion) was used. For this purpose, according to study of Henseler, Ringle, and Sinkovics (2009) and with respect to the results of the measures presented in Table 4, it can be concluded that the model has predicatively power higher than average. After validating the measurement model and fitting the structural model, in order to control the overall fit of the model, a measure known as the GoF (Goodness of Fit) was used. Since the aforementioned measure was 0.43 ; therefore, according to the studies of Wetzels, Odekerken-Schroder and Van Oppen (2009), the overall fit of the model was approved as strong.

After investigating the fit of the measurement model and structural model and perfect fit models, the hypotheses were tested. Therefore, the result obtained from any of the hypotheses, standardized coefficients of the paths relevant to any hypotheses and as well as the results of hypothesis testing were presented in Table 5.

Table 5

The Results of the Hypothesis

\begin{tabular}{cccccc}
\hline & $\begin{array}{c}\text { Independent } \\
\text { Variables }\end{array}$ & Effect & $\begin{array}{c}\text { Dependent } \\
\text { Variables }\end{array}$ & Estimate & T-statistics \\
\hline $\mathrm{H}_{1}$ & $\begin{array}{c}\text { Strategic } \\
\text { Leadership }\end{array}$ & $\rightarrow$ & $\begin{array}{c}\text { Employees' } \\
\text { Empowerment }\end{array}$ & 0.45 & 8.83 \\
\hline $\mathrm{H}_{2}$ & $\begin{array}{c}\text { Employees' } \\
\text { Empowerment }\end{array}$ & $\rightarrow$ & Job Satisfaction & 0.30 & 5.97 \\
\hline $\mathrm{H}_{3}$ & $\begin{array}{c}\text { Strategic } \\
\text { Leadership }\end{array}$ & $\rightarrow$ & Job Satisfaction & 0.47 & 10.24 \\
\hline
\end{tabular}

$* \mathrm{p} \quad 0.05, * * \mathrm{p} \quad 0.01$ 
The results of hypothesis testing and coefficient significance as shown in Table 5 indicate that all hypotheses are confirmed. In Figure 2, all hypotheses are displayed in the final model.

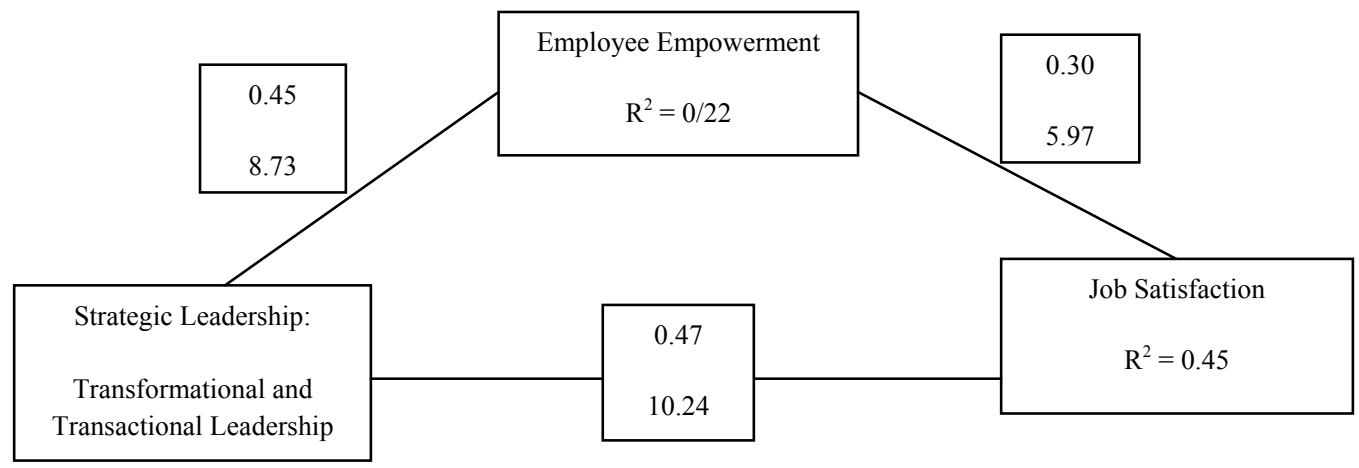

Figure 2. The final results of the proposed research model

As shown in Figure 2, it is observed that all relationships of conceptual model have been approved and according to the GOF calculated, the overall fit of the model is be approved too. Thus, the basis of this study was approved and determined that the style of strategic leadership which is characterized by its foresight and motivation could make employee develop, empower and finally be satisfied.

\section{Discussion and Conclusion}

In this article, the influence of the strategic leadership on Guilan University employee empowerment and job satisfaction were investigated. The importance of the afore-mentioned issue regarding developing a new approach based on a combination of strategic management and leadership concepts lies in the evaluation of relationship of these three variables in the organization. In this study, after designing the related structural equation model, the fitness of the measures and designed structures were tested and then the measures of empowerment and job satisfaction were excluded. After determining the fitness of the model for predicting employees' job satisfaction, the hypotheses were tested and the following results were obtained. First, strategic leadership had positive impact on employees' empowerment. This result confirmed the results of previous studies (Bass et al., 2003, B. J. Davies \& B. Davies, 2006; Esfahani et al., 2013, Hasanpur, Abbasi, \& Norouzi, 2011; Mir Kamali et al., 2010). Second, employees' empowerment had a positive impact on employees' job satisfaction. This finding was consistent with previous studies of Mir Kamali et al. (2009, 2010). The third result obtained from this study was that strategic leadership influenced on employees' job satisfaction. This result was in line with the studies of Avolio (1999), Bani-Hashemian et al. (2011), Ehsani et al. (2012), Kharrazi et al. (2013), Nguni, Sleegers, and Denessen (2006).

This study also revealed that the coefficient of determination of employees' empowerment is 0.22 which specified that only 22 per cent of the changes of this variable were on the base of changes in the strategic leadership. The coefficient of determination of employee satisfaction was 0.45 per cent which showed that the percentage of changes of employee job satisfaction was influenced by the changes in strategic leadership and the empowerment. The 
rest was influenced by the other factors. It was also shown that employees' job satisfaction, in addition to being directly related to employees' perceptions of leadership style. It could also indirectly be created by impact of the style of strategic leadership on empowerment. Finally, it was proved that all of above-mentioned points could increase employees' motivation and commitment and consequently improved efficiency, productivity, and overall organizational performance of organization.

According to the results of the study, it is suggested that the University of Guilan invest more in improving strategic leadership and employees' empowerment, because 45 per cent of employees' satisfaction is due to changes in these two variables. For future research, it is suggested that other factors influencing job satisfaction be identified and evaluated in advance. For this purpose, the variables such as independent, mediator, and intervention variables like administrative infrastructure, internal marketing, employment facilities, job security, job expectations can be used. It is also possible to evaluate the effects of strategic leadership on variables such as motivation, organizational performance, and development of innovation.

\section{References}

Akhtar Shojaei, E., Nazari, A., \& Vahidi, R. (2004). Style of leadership of managers and its relationship with job satisfaction of nurses working in teaching hospitals affiliated to Tabriz University of Medical Sciences. Hakim Research Journal, 4 , $20-25$.

Al Hijji, K. Z. (2014). Strategic management model for academic libraries. Procedia - Social \& Behavioral Sciences, 147, 9-15.

Amundsen, S., \& Martinsen, O. L. (2014). Empowering leadership: Construct clarification, conceptualization, and validation of a new scale. The Leadership Quarterly, 25, 487-511.

Antoniou, P. H., \& Ansoff, H. I. (2004). Strategic management of technology. Technology Analysis \& Strategic Management, 16(2), 275-291.

Avery, R. E., Smillie, L. D., \& Fife-Schaw, C. R. (2015). Employee achievement orientations and personality as predictors of job satisfaction facets. Personality \& Individual Differences, 76, 56-61.

Avolio, B. J., Bass, B. M., \& Jung, D. I. (1999). Re-examining the components of transformational and transactional leadership using the multifactor leadership questionnaire. Journal of Occupational \& Organizational Psychology, 72, 441-462.

Bani-Hashemian, K., Golestan Jahromi, F., Ganbari Pirkashani, N., \& Sharafi, M. (2011). Explores the relationship between public health and leadership style and its effect on job satisfaction in Shiraz. Paramedical Faculty of Tehran University of Medical Sciences, 5, 32-40.

Barnes, D., Hinton, M., \& Mieczkowska, S. (2004). The strategic management of operations in e-business. Production, Planning, \& Control, 15(5), 484-494.

Bass, B. M. (1985). Leadership and performance beyond expectations. New York: Free Press.

Bass, B. M. (1998). Transformational leadership: Industrial, military, and educational impact. Mahwah, NJ: Lawrence Erlbaum Associates, Inc.

Bass, B. M., Avolio, B. J., Jung, D. I., \& Berson, Y. (2003). Predicting unit performance by assessing transformational and transactional leadership. Journal of Applied Psychology, 88, 207-218.

Bellou, V., \& Andronikidis, A. (2008). The impact of internal service quality on customer service behavior: Evidence from the Banking Sector. International Journal of Quality \& Reliability Management, 25(9), 943-954.

Bessokirnaia, G. P., \& Temnitskii, A. L. (2015). Job satisfaction and satisfaction with life. Sociological Research, 40(4), 612.

Beteta, H. C. (2006). What is missing in measures of women's empowerment? Journal of Human Development, 7(2), 221241.

Burke, R. J., Oberklaid, F., \& Burgess, Z. (2005). Organizational values, job experiences, and satisfactions among female and male psychologists. Community, Work, \& Family, 8(1), 53-68.

Cahill, K. E., McNamara, T. K., Pitt-Catsouphes, M., \& Valcour, M. (2015). Linking shifts in the national economy with changes in job satisfaction, employee engagement, and work-life balance. Journal of Behavioral \& Experimental Economics, 56, 40-54.

Chen, L. H., Liaw, S. Y., \& Lee, T. Z. (2003). Using an HRM pattern approach to examine the productivity of manufacturing firms: An empirical study. International Journal of Manpower, 24(3), 299-318.

Conger, J., \& Kanungo, R. (1988). The empowerment process: Integrating theory and practice. Academy of Management Review, 13(3), 471-482. 
Chan, S. H., \& Qiu, H. H. (2011). Loneliness, job satisfaction, and organizational commitment of migrant workers: Empirical evidence from China. The International Journal of Human Resource Management, 22(5), 1109-1127.

Chang, L. C., Shih, C. H., \& Lin, S. M. (2010). The mediating role of psychological empowerment on job satisfaction and organizational commitment for school health nurses: A cross-sectional questionnaire survey. International Journal of Nursing Studies, 47, 427-433.

Chin, W. W. (1998). Issues and opinion on structural equation modeling. MIS Quarterly, 22(1),7-16.

Cronbach, L. (1951). Coefficient alpha and the internal structure of tests. Psychometrical, 16, 297-334.

Davies, B. (2003). Rethinking strategy and strategic leadership in schools. Educational Management \& Administration, 31(3), 295-312.

Davies, B. J., \& Davies, B. (2006). Developing a model for strategic leadership in schools. Educational Management, Administration, \& Leadership, 34(1), 121-139.

Diamantopoulos, A., Sarstedt, M., Fuchs, C., Wilczynski, P., \& Kaiser, S. (2012). Guidelines for choosing between multiitem and single-item scales for construct measurement: A predictive validity perspective. Journal of the Academy of Marketing Science, 40(3), 434-449.

Ehsani, M. Sedaghati, M., \& Ghanbari, A. (2012). Evaluation of the relationship of head nurses' leadership style to nurses' job satisfaction of nurses working in medical-surgical wards of hospitals affiliated to Tonekabon Islamic Azad University. Journal of Education \& Ethics in Nursing, 1(1), 14-20.

El-Hout, M. S. (1994). Strategic planning for educational system: Necessity and methodology. Journal of Educational Planning \& Administration, 8(1), 47-62.

Ertürk, A., \& Vurgun, L. (2015). Retention of IT professionals: Examining the influence of empowerment, social exchange, and trust. Journal of Business Research, 68, 34-46.

Esfahani, A. N., Ghazanfari, A., \& Amerinasab, S. (2013). The relationship between ethical leadership and employees' empowerment of the employees. Journal of Research in Human Resource Management, 5(1), 107-128.

Esmaeili, N. (2015). Strategic management and its application in modern organizations. International Journal of Organizational Leadership, 4, 118-126.

Fidler, B. (1989). Strategic management: where is the school going? In B. Fidler \& G. Bowles (Eds.), Effective local management of schools: A strategic approach (pp. 19-35). Essex: Longman.

Fornell, C., \& Larcker, D. (1981). Structural equation models with unobservable variables and measurement error. Journal of Marketing Research, 18(1), 39-50.

Gannon, J. M., Roper, A., \& Doherty, L. (2015). Strategic human resource management: Insights from the international hotel industry. International Journal of Hospitality Management, 47, 65-75.

Ghahremani Germi, M., \& Hasanzadeh, M. (2015). The relative importance of organizational conditions in empowering managers. International Journal of Organizational Leadership, 4, 225-237.

Ghahremani Germi, M., \& Hasanzadeh, M. (2015). Describing model of empowering managers by applying structural equation modeling: A case study of universities in Ardabil. International Journal of Organizational Leadership, 4, 127143.

Gius, M. (2013). The effects of merit pay on teacher job satisfaction. Applied Economics, 45(31), 4443-4451.

Grube, A., Schroer, J., Hentzschel, C., \& Hertel, G. (2008). The event reconstruction method: An efficient measure of experience-based job satisfaction. Journal of Occupational \& Organizational Psychology, 81, 669-689.

Hambrick, D. C., \& Mason, P. A. (1984). Upper echelons: The organization as a reflection of its top managers. Academy of Management Review, 9(2), 193-206.

Hasanpur, A., Abbasi, T., \& Norouzi, M. (2011). Surveying the role of transformational leadership in empowering employees. Research of Management in Iran, 15(1), 159-179.

Hayes, B. E. (1994). How to measure empowerment. Quality Progress, 27(2), 41-46.

Hennestad, B. J. (1998). Empowering by dedepowering: Towards an HR strategy for realizing the power of empowerment. The International Journal of Human Resource Management, 9(5), 934-953.

Henseler, J., Ringle, C. M., \& Sinkovics, R. R. (2009). The use of partial least squares path modeling in international marketing. In R. R. Sinovics \& P. N. Ghauri (Eds.), Advances in international marketing (pp. 277-320). Bingley: Emerald.

Hill, N. S., Kang, J. K., \& Seo, M. G. (2014). The interactive effect of leader-member exchange and electronic communication on employee psychological empowerment and work outcomes. The Leadership Quarterly, 25, 772-783.

Hulland, J. (1999). Use of partial least squares (PLS) in strategic management research: A review of four recent studies. Strategic Management Journal, 20(2), 195-204.

Jackson, S. E., Schuler, R. S., \& Jiang, K. (2014). An aspirational framework for strategic human resource management. The Academy of Management Annals, 8(1), 1-56.

Jansen, J. J. P., Dusya, V., \& Crossan, M. (2009). Strategic leadership for exploration and exploitation: The moderating role of environmental dynamism. The Leadership Quarterly, 20(1), 5-18.

Jones, R. J., \& Sloane, P. J. (2007). Low pay, higher pay, and job satisfaction in Wales. Spatial Economic Analysis, 2(2), $197-214$.

Jung, S., \& Yoon, H. H. (2013). Do employees' satisfied customers respond with a satisfactory relationship? The effects of employees' satisfaction on customers' satisfaction and loyalty in a family restaurant. International Journal of Hospitality Management, 34, 1-8.

Kanagaretnam, K., Mestelman, S., Nainar, S. M. K., \& Shehata, M. (2014). Transparency and empowerment in an investment environment. Journal of Business Research, 67, 2030-2038.

Keupp, M. M., Palmié, M., \& Gassmann, O. (2012). The strategic management of innovation: A systematic review and paths for future research. International Journal of Management Reviews, 14, 367-390. 
Kharrazi, S. K., Mir Kamali, S. M., \& Torki, A. (2013). Organizational servant leadership and employees' job satisfaction. Perspective of Public Management, 14, 11-18.

Kurland, H., \& Hasson-Gilad, D. R. (2015). Organizational learning and extra effort: The mediating effect of job satisfaction. Teaching \& Teacher Education, 49, 56-67.

Larkin, M., \& Milne, A. (2014). Careers and empowerment in the UK: A critical reflection. Social Policy \& Society, 13(1), 25-38.

Lenkov, D. S., Judge, W., \& Wright, P. (2005). Strategic leadership and executive innovation influence: An international multi-cluster comparative study. Strategic Management Journal, 26, 665-682.

Lin, C. Y. Y. (2002). Empowerment in the service industry: An empirical study in Taiwan. The Journal of Psychology: Interdisciplinary \& Applied, 136(5), 533-554.

Liu, M., Chiu, W., \& Fellows, R. (2007). Enhancing commitment through work empowerment. Engineering, Construction, \& Architectural Management, 14(6), 568-580.

Maranville, S. (2011). The art of strategic management: A case-based exercise. Journal of Management Education, 35(6), 782-807.

Masihabadi, A., Rajaei, A., Koloukhi, A. S., \& Parsian, H. (2015). Effects of stress on auditors' organizational commitment, job satisfaction, and job performance. International Journal of Organizational Leadership, 4, 303-314.

Menon, S. T. (2001). Employee empowerment: An integrative psychological approach. Applied Psychology: An International Review, 50(1), 153-180.

Metle, M. K. (2001). Education, job satisfaction, and gender in Kuwait. International Journal of Human Resource Management, 12(2), 311-332.

Mir Kamali, S. M., Hayat, A. A, Norouzi, A., \& Jarahi, N. (2009). The relationship between psychological empowerment, job satisfaction, and organizational commitment among employees of Tehran University. Daneshvar Scientific \& Research Journal, 16(39), 15-30.

Mir Kamali, S. M., \& Nasti Zaei, N. (2010). Examining the relationship between psychological empowerment and job satisfaction among nurses. Journal of Urmia Nursing \& Midwifery Faculty, 8(2), 104-113.

Nguni, S., Sleegers, P., \& Denessen, E. (2006). Transformational and transactional leadership effects on teachers' job satisfaction, organizational commitment, and organizational citizenship behavior in primary schools: The Tanzanian case. School Effectiveness \& School Improvement, 17(2), 145-177.

Nunnally, J. (1978). Psychometric theory ( $2^{\text {nd }}$ ed.). New York: McGraw-Hill.

Okumus, F., Wong, K. K. F., \& Altinay, L. (2009). Are we teaching strategic management right? Journal of Teaching in Travel \& Tourism, 8(4), 329-350.

Ozaralli, N. (2003). Effects of transformational leadership on empowerment and team effectiveness. Leadership \& Organization Development Journal, 24(6), 335-344.

Pawar, B. S., \& Eastman, K. K. (1997). The nature and implications of contextual influences on transformational leadership: A conceptual examination. Academy of Management Review, 22(1), 80-109.

Pezeshki-Rad, G., Biglari, N., \& Zamani-Miandashti, N. (2011). Empowering agricultural production cooperatives: A nationwide survey of definitions and strategies in Iran. Human Resource Development International, 14(5), 633-641.

Poister, T. H. (2005). Strategic planning and management in state departments of transportation. International Journal of Public Administration, 28, 1035-1056.

Reich, A. Z. (2015). Should strategic market management replace strategic management as the planning model for restaurant decision- making? Journal of Food Service Business Research, 5(1), 23-43.

Seibert, S., Silver, S., \& Randolph, W. (2004). Taking empowerment to the next level: A multiplelevel model of empowerment, performance, and satisfaction. Academy of Management Journal, 47(3), 332-350.

Tutuncu, O., \& Kozak, M. (2007). An investigation of factors affecting job satisfaction. International Journal of Hospitality \& Tourism Administration, 8(1), 1-19.

Ueno, A. (2008). Is empowerment really a contributory factor to service quality? The Service Industries Journal, 28(9), $1321-1337$.

Vera, D., \& Crossan, M. (2004). Strategic leadership and organizational learning. Academy of Management Review, 29(2), 222-240.

Waldman, D. A., Siegel, D., \& Javidan, M. (2006). Components of CEO transformational leadership and corporate social responsibility. Journal of Management Studies, 43(8), 1703-1725.

Weinberg, M. L., \& Lewis, M. S. (2009).The public value approach to strategic management. Museum Management \& Curatorship, 24(3), 253-269.

Wetzels, M., Odekerken-Schroder, G., \& Van Oppen, C. (2009). Using PLS path modeling for assessing hierarchical construct models: Guidelines and empirical illustration. MISQuarterly, 33(1), 177-199.

Wolfe, K., \& Kim, H. J. (2013). Emotional intelligence, job satisfaction, and job tenure among hotel managers. Journal of Human Resources in Hospitality \& Tourism, 12(2), 175-191.

Yagil, D. (2006). The relationship of service provider power motivation, empowerment, and burnout to customer satisfaction. International Journal of Service Industry Management, 17(3), 258-270.

Yorio, P. L., Willmer, D. R., \& Moore, S. M. (2015). Health and safety management systems through a multilevel and strategic management perspective: Theoretical and empirical considerations. Safety Science, 72, 221-228.

Yukl, G. (1994). Leadership in organizations (3 ${ }^{\text {rd }}$ ed.). Englewood Cliffs, NJ: Prentice Hall.

Zahedi, S. (1999). A comparative study of leadership styles. Journal of Governmental Management, 45, 14-32. 